\title{
Long Term Effects of Continuous Rice Cultivation on Bulk Density and Hydraulic Conductivity of Gharbia Governorate Soils
}

\author{
A. A. Abd El-Halim \\ Soil and Water Department, Faculty of Agriculture, Tanta \\ University, Tanta,Egypt.
}

\begin{abstract}
7 HE PRESENT study was carried out to investigate the effect of continuous non-puddling (dry tillage) transplanting rice cultivation for 5, 7 and 10-year period on soil bulk density and saturated hydraulic conductivity as soil quality indicators at AlGharbia Governorate located in the Middle Nile Delta, Egypt. The results indicated that continuous rice cultivation for 5 to 10 years period resulted in slight migration of silt and clay contents to lower depths, degradation in soil bulk density and decrease in saturated hydraulic conductivity. In addition, continuous rice cultivation was not substantial enough to eliminate dissimilarities of bulk density among soil depths. Moreover, positive relationship has been observed between soil bulk density and finer particles (clay and silt) due to increased number of cultivation years and with soil depths. On contrary, negative relationship has been observed between soil hydraulic conductivity and finer particles due to increased number of cultivation years and with soil depths.
\end{abstract}

Keywords: Non-puddle rice, Soil properties, Continuous cultivation

Rice became a dominant crop in the Middle Nile Delta of Egypt for the past two decades. In the Middle Nile Delta, where the irrigation network supplies enough water, and where heavy clay soils are present, farmers preferred to cultivate rice over cotton and maize in summer because of the availability of high-yielding rice varieties and high economic returns. Therefore, rice, mainly, replaced cotton and maize areas to become the major summer crop on the Egyptian agricultural map (Okasha et al., 2009).

Traditionally, the main patterns of rice and other crop are rice-wheat and rice- clover. In conventional rice rotation systems, farmers drain the fields after harvesting rice and then plant wheat or Egyptian clover crop. Consequently, the cropping systems are becoming more and more intensified and whenever possible, many farmers grow rice during summer season after wheat or clover crop continuously for each year. In the Middle Nile Delta of Egypt, submergence, non-puddling (dry tillage) and continuous flooding are common practices in rice cultivation. Rice's cultivation under flooded condition can result in temporary and permanent changes in the soil properties. Furthermore, because of longterm submergence and mineral fertilizer application, rice soils experience degradation of soil quality, such as breakdown of stable aggregation and 
deterioration of soil organic matter, which negatively affects agricultural sustainability (Boparai et al., 1992 and Mohanty \& Painuli, 2004).

Soil quality is a term used to describe the health of agricultural soils. It has been suggested as an indicator for evaluating sustainability of soil and crop management practices (Gregorich et al., 1994 and Doran \& Zeiss, 2000). A large number of soil properties have been proposed as indicators of soil quality, e.g., soil texture (aggregate stability), bulk density and saturated hydraulic conductivity. In addition, soil physical properties are indicators of the impact of soil and crop management practices. For example, changes in aggregate stability may serve as early indicators of recovery or degradation of soils, and high bulk density is an indicator of low soil porosity and soil compaction (USDA, 2008). However, few studies have been done to determine the effect of continuously non-puddle transplanting rice cultivation on soil hydro-physical properties.

Therefore, the present study was conducted to investigate the effect of continuous non-puddling (dry tillage) transplanting rice cultivation for different periods 5, 7 and 10 years on the soil quality indicators, i.e., texture (sand, silt and clay content) bulk density and hydraulic conductivity.

\section{Material and Methods}

\section{Location description and rice cultivation method}

The studied area is about $15 \mathrm{~km}$ from the Faculty of Agriculture at Tanta City, Al-Gharbia Governorate, Egypt. It extends between $30^{\circ} 47^{\prime} \mathrm{N}$ latitude, $31^{\circ}$ $00^{\prime}$ E longitude, and altitude of $20 \mathrm{~m}$ above mean sea level. In the region under investigation, rice seedling has been transplanted manually under non-puddling (dry tillage) conditions and continuous flooding for about seven centimeters depth waters every six-day intervals through the growing season as recommended by Rice Research and Training Center (RRTC) in Egypt.

\section{Soil sampling and laboratory investigations}

Three fields have been cultivating continuously with non-puddle rice since 5,7 and 10 years in addition to a fourth field without rice cultivation (control) were selected to the present study. Each field covers an area of about one feddan $\left(4200 \mathrm{~m}^{2}\right)$ and has the same agronomic practices of rice cultivation. All the studied fields are located within the similar soil-mapping units.

Undisturbed soil cores ( $424 \mathrm{~cm}^{3}$ volume) in a twenty replication were taken from each field at different soil depths (each $10 \mathrm{~cm}$ up to $30 \mathrm{~cm}$ depth) after rice harvesting in October, 2010.

Bulk density (BD) was determined by the core method as it described by Bashour and Sayegh (2007) as follows: A double cylinder, hammer driven core sampler was used to sample the soil profile at an interval of $10 \mathrm{~cm}$. The samples were next oven dried at $105^{\circ} \mathrm{C}$ for $24 \mathrm{hr}$ after which they were weighed. Then $\mathrm{BD}$ was then calculated using the following equation:

Egypt. J. Soil Sci. 53, No. 2 (2013) 


\section{$\mathrm{BD}=$ Mass of oven dried soil/Volium of the core sample}

Saturated hydraulic conductivity $\left(\mathrm{K}_{\mathrm{S}}\right)$ was determined by the falling head method as it described by Reynolds (2008) as follows:

The undisturbed core samples representing each layered profile were covered at one end, with a piece of Muslin cloth held in place with the aid of rubber bands and allowed to stand overnight in water to ensure complete saturation. These saturated samples were after that arranged into a permeameter, velocity of flow and changes in hydraulic heads were determined. Saturated hydraulic conductivity $\left(\mathrm{K}_{\mathrm{s}}\right)$ was then calculated using the following equation:

$$
\mathrm{K}_{\mathrm{s}}=(\mathrm{aL} / \mathrm{At}) \ln \left(\mathrm{h}_{1} / \mathrm{h}_{2}\right)
$$

Where, $\mathrm{A}$ is the inside cross-sectional area of the water tank; a is the inside cross-sectional area of the standpipe; $h_{1}$ is the distance to bottom of the beaker before the test, and $\mathrm{h}_{2}$ is the distance to bottom of the beaker after the test.

In addition, loose soil samples were also collected with an auger for the same depths. Samples were then air-dried, crushed, and passed through a 2-mm sieve to determine soil texture by the pipet method (Day, 1965).

\section{Statistical analysis}

The data were analyzed statistically using MSTATC $^{\mathrm{TM}}$ version 2.0 (MSTAT-C, 1983). The significant differences between means were tested using Duncan's Multiple Range Test (DMRT) at 5\% level of probability (Duncan, 1955).

\section{Results and Discussion}

\section{Soil separates $(\%)$}

Years of rice cultivation had significantly affected on contents of sand, silt and clay $(\mathrm{P} \leq 0.05)$. On the other hand, soil depths and its interaction with years of rice cultivation had not significantly affected on contents of sand, silt and clay (Table 1). The highest percentage of sand (20.78\%) was obtained from soil with 10 years of rice cultivation, whereas the lowest percentage $(15.67 \%)$ was obtained from soil that has never been cultivated with rice before (non-rice cultivation). The highest percentage of silt and clay (35.11\% and $49.22 \%$ ) was obtained from soil with 10 years of rice cultivation, whereas the lowest percentage (32.22 and 47\%) was obtained from soil with non-rice cultivation. These results in agreement with that reported by Oguike and Mbagwu (2009) under continue different land use type's cultivation for four years, they found that clay content increased with depth while sand decreased. Statistically, there is no difference between percentage of silt and clay obtained from the soil with 5,7 and 10 - year period of rice cultivation. 
TABLE 1. Effect of years of cultivation rice on the distribution of sand, silt and clay fraction percentages in the different soil depths.

\begin{tabular}{|l|c|c|c|c|c|c|}
\hline Soil & Soil depth & \multicolumn{4}{|c|}{ Years of cultivation } & \multirow{2}{*}{ Mean } \\
\cline { 3 - 6 } & $(\mathbf{c m})$ & $\mathbf{0}^{\#}$ & $\mathbf{5}$ & $\mathbf{7}$ & $\mathbf{1 0}$ & \\
\hline & $0-10$ & 22.33 & 19.33 & 19.67 & 18.00 & 19.83 \\
\hline Property & $10-20$ & 20.00 & 17.00 & 16.67 & 15.67 & 17.34 \\
\hline & $20-30$ & 20.00 & 14.67 & 14.33 & 13.33 & 15.58 \\
\hline & Mean & $20.78 \mathrm{a}$ & $17.00 \mathrm{~b}$ & $16.89 \mathrm{~b}$ & $15.67 \mathrm{~b}$ & \\
\hline & $0-10$ & 31.67 & 33.67 & 34.00 & 34.00 & 33.34 \\
\hline Silt (\%) & $10-20$ & 33.00 & 34.67 & 35.00 & 35.00 & 34.42 \\
\hline & $20-30$ & 32.00 & 35.67 & 36.00 & 36.33 & 35.00 \\
\hline & Mean & $32.22 \mathrm{~b}$ & $34.67 \mathrm{a}$ & $35.00 \mathrm{a}$ & $35.11 \mathrm{a}$ & \\
\hline & $0-10$ & 46.00 & 47.00 & 46.33 & 48.00 & 46.84 \\
\hline Clay (\%) & $10-20$ & 47.00 & 48.33 & 48.33 & 49.33 & 48.24 \\
\hline & $20-30$ & 48.00 & 49.67 & 49.67 & 50.33 & 49.42 \\
\hline & Mean & $47.00 \mathrm{~b}$ & $48.33 \mathrm{a}$ & $48.11 \mathrm{a}$ & $49.22 \mathrm{a}$ & \\
\hline
\end{tabular}

\# Non-rice cultivation .

${ }^{\$}$ Numbers with different letters are significantly different .

The variations in sand, silt and clay contents were marginal among the different years of rice cultivation (Fig. 1). These variations may be due to continuous cropping, increased years of cultivation and intensive land use, which affected the particle size distribution (Kauffmann et al., 1998 and Nkana \& Tonye, 2003). Another explanation may be due to the strong leveling of soil during land preparation, which results in the mixing of different soil particles, particularly in first $20 \mathrm{~cm}$ of topsoil. This explanation agrees with the results which indicated a significant effect of land leveling on sand, silt and clay content (Miller et al., 1988 and Unger et al., 1990). The results showed that fine-earth fraction has been dominated by clay content, then by silt content, whereas sand content was the least amount in all soil depths. Furthermore, the average of silt and clay content obtained from subsoil layers $(10-20$ and $20-20 \mathrm{~cm})$ were significantly more than that obtained from topsoil layer $(0-10 \mathrm{~cm})$, whereas the relative proportion of sand particles was greaten in topsoil layer than in subsoil layers, as consistently reported by many authors (Nizami et al., 1997, Agoumé and Birang, 2009 and Asadu et al., 2010). Generally, the dominant texture was clayey, and the variation in particle size distribution across the different soil depths was small. The great silt and clay content with depth indicates slight migration of silt and clay to the lower depths with percolating irrigation water in rice fields, as reported by some other researchers (Asadu and Bosah, 2003 and Singh et al., 2009). 


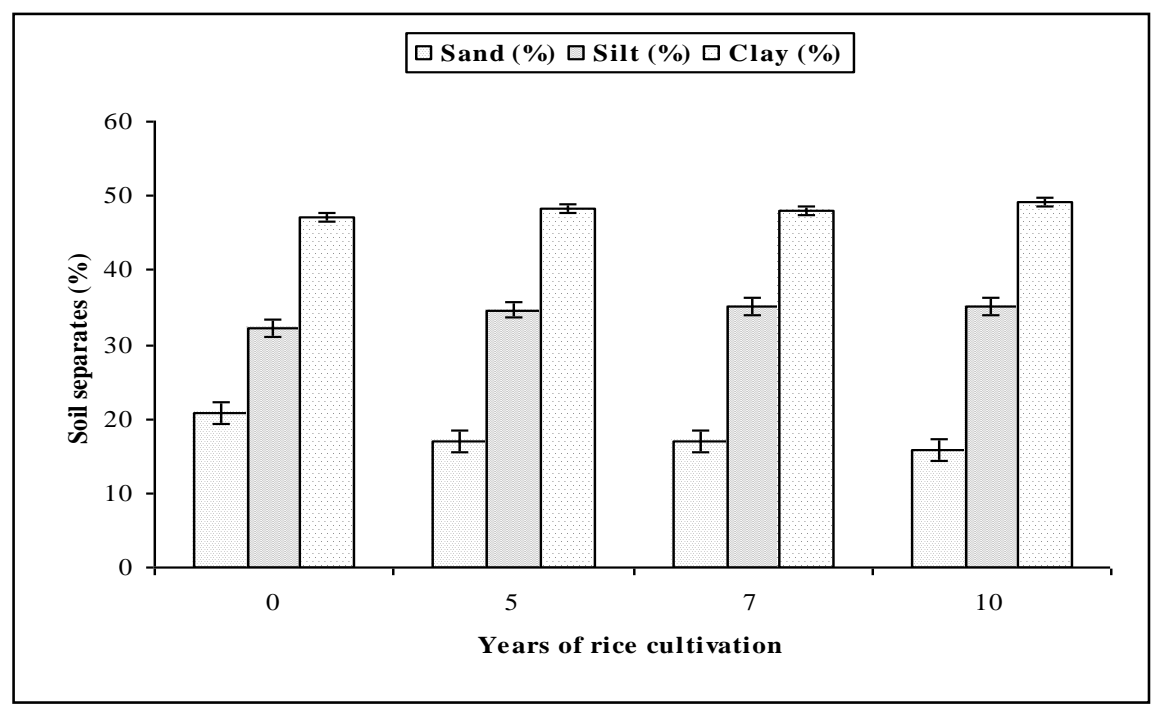

Fig. 1. Effect of years of rice cultivation on soil contents of sand, silt and clay.

Bulk density ( $\left.B D, \mathrm{~g} \mathrm{~cm}^{-3}\right)$

Years of rice cultivation and soil depths had significantly affected on BD, whereas interaction between them had not significantly affected on BD (Table 2). Soil with rice cultivation for 5, 7 and 10 years period increased BD by 7.2, 9.9 and $15.79 \%$ compared to soil with non-rice cultivation. The highest BD (1.45 g $\mathrm{cm}^{-3}$ ) was observed from soil with 10-year of rice cultivation, followed by soil with 7 and 5 years of rice cultivation $\left(1.42\right.$ and $\left.1.38 \mathrm{~g} \mathrm{~cm}^{-3}\right)$ whereas, the least BD $\left(1.28 \mathrm{~g} \mathrm{~cm}^{-3}\right)$ was observed from soil with non- rice cultivation (Fig. 2). The BD values, $1.37,1.38$ and $1.39 \mathrm{~g} \mathrm{~cm}^{-3}$, were obtained in depths of 0 to 10,10 to 20 and 20 to $30 \mathrm{~cm}$, respectively (Table 2 ).

TABLE 2. Effect of years of cultivation rice on bulk density (BD) and saturated hydraulic conductivity $\left(K_{S}\right)$ in the different soil depths.

\begin{tabular}{|c|c|c|c|c|c|c|}
\hline Soil & \multirow{2}{*}{$\begin{array}{l}\text { Soil depth } \\
\text { (cm) }\end{array}$} & \multicolumn{4}{|c|}{ Years of cultivation } & \multirow{2}{*}{ Mean $\$$} \\
\hline Property & & $\mathbf{0}^{\#}$ & 5 & 7 & 10 & \\
\hline & $0-10$ & 1.27 & 1.37 & 1.41 & 1.44 & $1.37 \mathrm{~b}$ \\
\hline \multirow{3}{*}{$\begin{array}{c}\mathrm{BD} \\
\left(\mathrm{g} \mathrm{cm}^{-3}\right)\end{array}$} & $10-20$ & 1.28 & 1.38 & 1.42 & 1.45 & $1.38 \quad \mathrm{a}$ \\
\hline & $20-30$ & 1.29 & 1.39 & 1.43 & 1.46 & $1.39 \mathrm{a}$ \\
\hline & Mean & $1.28 \mathrm{~d}$ & $1.38 \mathrm{c}$ & $1.42 \mathrm{~b}$ & $1.45 \mathrm{a}$ & \\
\hline \multirow{4}{*}{$\begin{array}{c}\mathrm{K}_{\mathrm{S}} \\
\left(\mathrm{cm} \mathrm{h}^{-1}\right)\end{array}$} & $0-10$ & 0.49 & 0.40 & 0.33 & 0.31 & $0.38 \mathrm{a}$ \\
\hline & $10-20$ & 0.47 & 0.38 & 0.30 & 0.28 & $0.36 \mathrm{~b}$ \\
\hline & $20-30$ & 0.45 & 0.36 & 0.27 & 0.25 & $0.33 \mathrm{c}$ \\
\hline & Mean & $0.47 \mathrm{a}$ & $0.38 \mathrm{~b}$ & $0.30 \mathrm{c}$ & $0.28 \mathrm{~d}$ & \\
\hline
\end{tabular}

\# Non-rice cultivation.

${ }^{\$}$ Numbers with different letters are significantly different. 


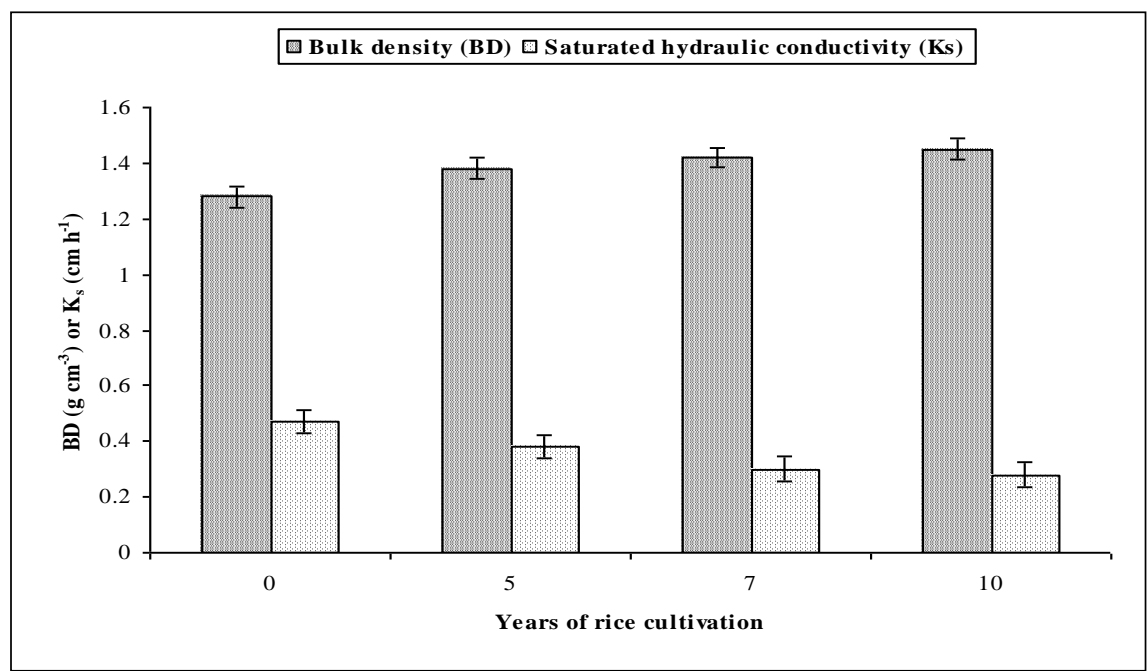

Fig. 2. Effect of years of rice cultivation on bulk density and saturated hydraulic conductivity.

The results indicated that after 10 to $20 \mathrm{~cm}$ depth, there was a slight difference in BD values. The highest BD $\left(1.46 \mathrm{~g} \mathrm{~cm}^{-3}\right)$ obtained from soil with 10 years of rice cultivation in 20 to $30 \mathrm{~cm}$ depth. The lowest BD $\left(1.27 \mathrm{~g} \mathrm{~cm}^{-3}\right)$ obtained from soil with non-rice cultivation in depth of 0 to $10 \mathrm{~cm}$. Increased $\mathrm{BD}$ with the increase of rice cultivation years may be due to fast settling of soil particles (Rautaray et al., 1997 and Mohanty et al., 2003). In general, the range of BD $\left(\mathrm{g} \mathrm{cm}^{-3}\right)$ for different types of soils found to be $1-1.5 \mathrm{~g} \mathrm{~cm}^{-3}, 1.13-1.20 \mathrm{~g}$ $\mathrm{cm}^{-3}, 1.2-1.28 \mathrm{~g} \mathrm{~cm}^{-3}$ and $1.35-1.48 \mathrm{~g} \mathrm{~cm}^{-3}$ for good soil, forest soil, grassland and cultivated soil, respectively (Bradshaw and Chadwick, 1980). Based on this finding, BD values were not within the range suitable for arable crop production, which means that continuous cultivation of rice causes a problem in bulk-density degradation. In addition, the results showed that BD was less in topsoil depths (0-10 and 10-20 cm) than in subsoil depth $(20-30 \mathrm{~cm})$. Settled particles and bulk density of the submerged soil were increased with time (Sharma and De Datta, 1985). Furthermore, subsurface compacting effect of the soil can be increased by prolonged flooded conditions for rice production, which causes slaking of soil aggregates (Motschenbacher et al., 2011). It is clearl that bulk density correlated highly with clay content, where bulk density increases with the increase of clay and silt (Fig. 3).

These results in the same line with that reported elsewhere by Chen et al. (1998) and Reichert et al. (2009). Though subsurface soil depth had typically greater clay content than that in topsoil depths and since bulk density directly related to clay content, it appears that the mixing of soil, due to continuously cultivation of rice, was not substantial enough to eliminate dissimilarities among soil depths. 


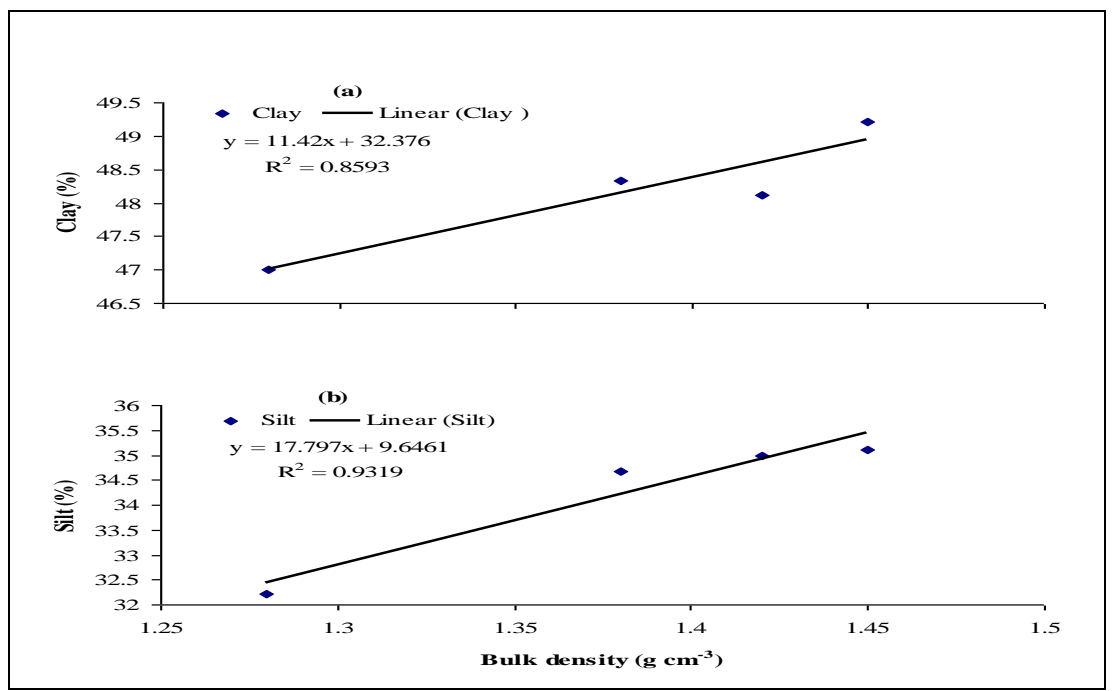

Fig. 3. Relationship between bulk density and soil contents of clay (a) and silt (b).

Saturated hydraulic conductivity $\left(K_{S}, \mathrm{~cm}^{-1}\right)$

Years of rice cultivation and soil depths had significantly affected on $K_{S}$, whereas interaction between them had not significantly affect on $\mathrm{K}_{\mathrm{S}}$ (Table 2). There were considerable differences in $\mathrm{K}_{\mathrm{S}}$ because of the increased rice cultivation years. These differences were extreme under soil with 5, 7 and 10year period of rice cultivation than in soil that has never been cultivated with rice before (non-rice cultivation). Highest $\mathrm{K}_{\mathrm{S}}\left(0.47 \mathrm{~cm} \mathrm{~h}^{-1}\right)$ was found in case of soil with non-rice cultivation, which it was significantly higher than in soil with five years of rice cultivation $\left(0.38 \mathrm{~cm} \mathrm{~h}^{-1}\right)$. Lowest $\mathrm{K}_{\mathrm{S}}$ of $0.28 \mathrm{~cm} \mathrm{~h}^{-1}$ found in the soil with 10 years of rice cultivation, and it was significantly lower than with seven years of rice cultivation $\left(0.30 \mathrm{~cm} \mathrm{~h}^{-1}\right)$ (Fig. 2). The $\mathrm{K}_{\mathrm{S}}$ asset value for the soil with non-rice cultivation was almost $1.24,1.57$ and 1.68 times higher than in soil with 5,7 and 10 -year period of rice cultivation, respectively. Relative to soil depth, the highest $\mathrm{K}_{\mathrm{S}}\left(0.38 \mathrm{~cm} \mathrm{~h}^{-1}\right)$ obtained in depth of 0 to 10 $\mathrm{cm}$, followed by $0.36 \mathrm{~cm} \mathrm{~h}^{-1}$ obtained in depth of 0 to $20 \mathrm{~cm}$, whereas the lowest $\mathrm{K}_{\mathrm{S}}\left(0.33 \mathrm{~cm} \mathrm{~h}^{-1}\right)$ obtained in depth of 20 to $30 \mathrm{~cm}$.

The $\mathrm{K}_{\mathrm{S}}$ decreased with the increase of $\mathrm{BD}$ (Fig. 4). This result in agreement with that reported by Oguike and Mbagwu (2009) under continue different land use type's cultivation for four years; they showed an inverse relationship with bulk density of the former decreasing as the latter increased with depth. This might be due to the decrease of water transmission pores, where $\mathrm{K}_{\mathrm{S}}$ depends on its amount and size in soil. Clogging of these channels reduced water transmission pores and resulted in decrease of $\mathrm{K}_{\mathrm{S}}$, as consistently reported by many authors (Rane and Varade, 1972, Sharma et al., 1991 and Behera et al., 2009). The $K_{S}$ seemed to be more in surface soil depths than in subsurface soil 
depths. This might be due to less BD in these depths. Furthermore, $\mathrm{K}_{\mathrm{S}}$ was decreased with the increase of finer particles (silt and clay, Fig. 5). This result agrees with those obtained under cleared forest land that had been subjected to continuous cultivation for seven years to ascertain selected crop or crop combinations (Asadu et al., 2010) and those obtained under continuous row crop cultivation for over 100 years (Mudgal et al., 2010).

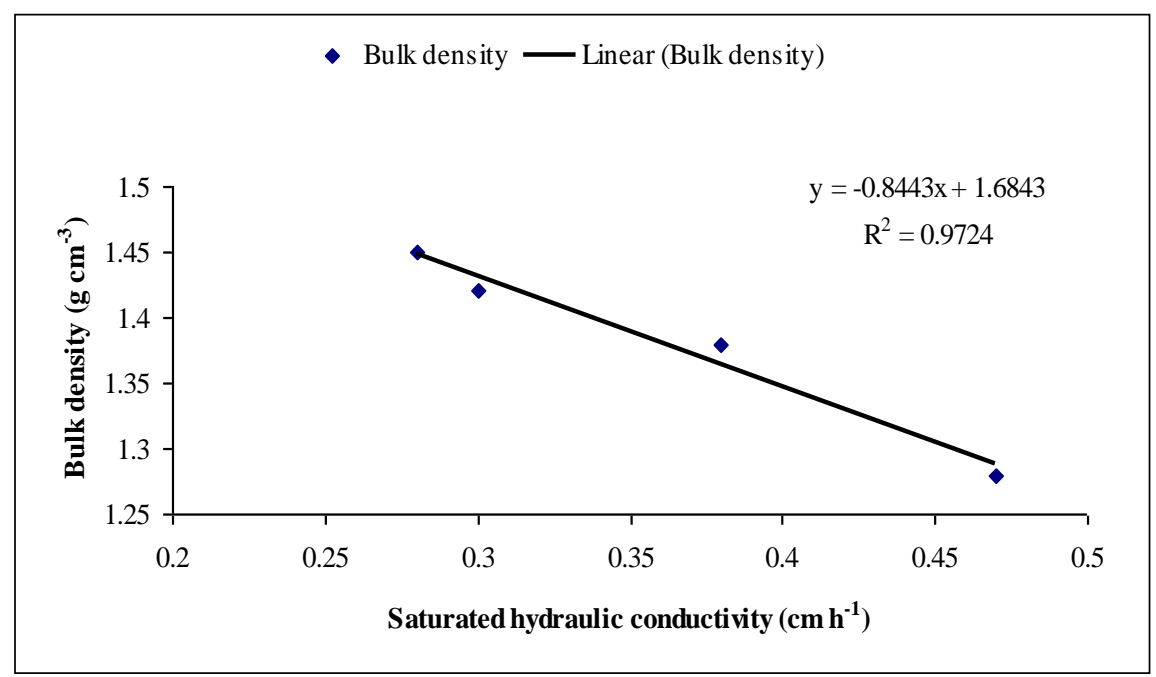

Fig. 4. Relationship between saturated hydraulic conductivity and soil bulk density.

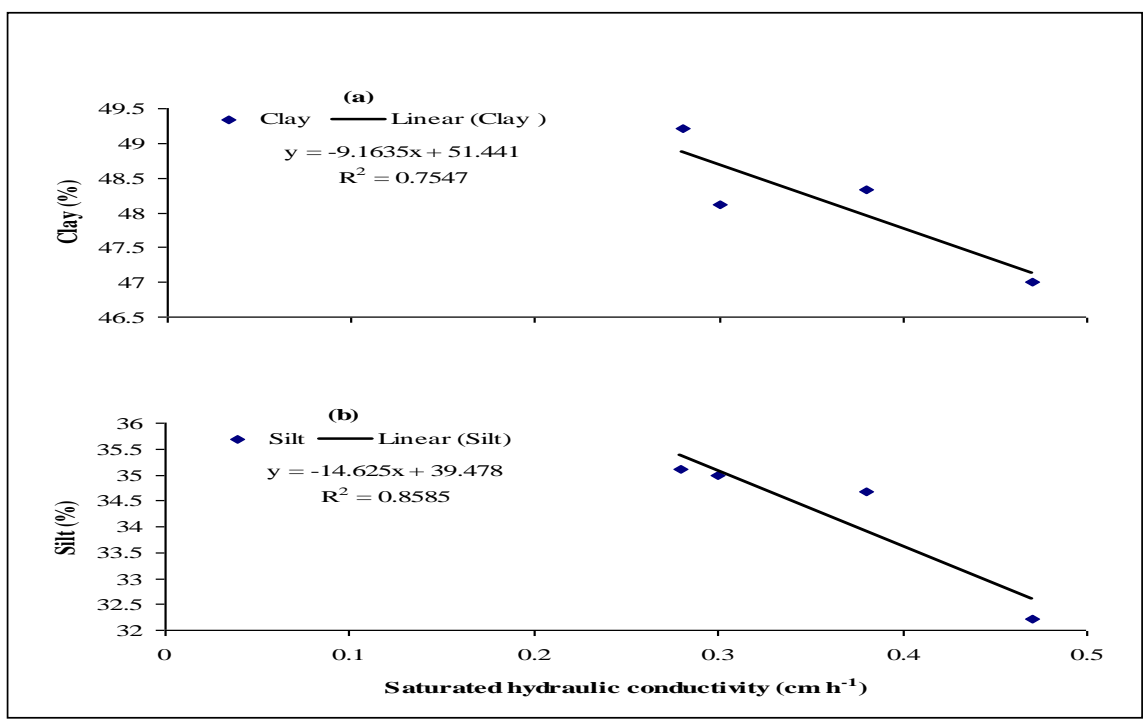

Fig. 5. Relationship between saturated hydraulic conductivity and soil contents of clay (a) and silt (b).

Egypt. J. Soil Sci. 53, No. 2 (2013) 


\section{Conclusions}

The present study was carried out to investigate the effect of continuous non-puddling (dry tillage) transplanting rice cultivation for 5, 7 and 10-year period on soil bulk density and saturated hydraulic conductivity at Al-Gharbia Governorate located in the Middle Nile Delta, Egypt. The results offer helpful insight into the effect of various years of rice cultivation on soil bulk density and saturated hydraulic conductivity. There were slight compaction and lower hydraulic conductivity among different years of rice cultivation and soil depths. The magnitude of these effects has accentuated in finer textured soils and under high temperature environments. Therefore, to sustain rice productivity, it is important to improve the deteriorated soil structure by adding organic manures, recycling crop residue and breaking the compacted soil layer at 15 to $30 \mathrm{~cm}$ deep with deep plowing between growing seasons.

\section{References}

Agoumé, V. and Birang, A.M. (2009) Impact of land-use systems on some physical and chemical soil properties of an oxisol in the humid forest zone of southern Cameroon. Tropicultura 27: 15-20.

Asadu, C.L.A and Bosah, C.S. (2003) A comparative study of the soils of the upper coal measure residua under cropped-grass-forest land continuum in eastern Nigeria. East. Afr. Agr. Forest J. 68: 205-212.

Asadu, C.L.A., Obasi, S.C. and Dixon, A.G.O. (2010) Variations in soil physical properties in a cleared forestland continuously cultivated for seven years in eastern nsukka, Nigeria. Commun. Soil Sci. Plant Anal. 41: 123-132.

Bashour, I.I. and Sayegh, A.H. (2007) "Methods of Analysis for Soils of Arid and SemiArid Regions", $1^{\text {st }}$ ed., FAO, USA.

Behera, B.K., Varshney, B.P. and Goel, A.K. (2009) Effect of Puddling on Puddled Soil Characteristics and Performance of Self-propelled Transplanter in Rice Crop. Agricultural Engineering International: The CIGRE Journal Vol. XI.

Boparai, B.S., Yadvinder-Singh and Sharma, B.D. (1992) Effect of green manuring with Sesbania aculeata on physical properties of soil and on growth of wheat in ricewheat and maize-wheat cropping systems in a semiarid region of India. Arid Soil Research \& Rehabilitation 6 (2):135-143.

Bradshaw, A.D. and Chadwick, M.J. (1980) "The Restoration of Land", Blackwell, Oxford.

Chen, Y., Tessier, S. and Rouffignat, J. (1998) Soil bulk density estimation for soil tillage system and soil texture. Trans. ASAE 41: 1601-1610.

Day, P.R. (1965) Particle fractionation and particle analysis. In: "Methods of Soil Analysis", C.A. Black (Ed.), pp. 562-566, Madison, Wisc, SSSA and ASA, 
Doran, J.W. and Zeiss, M.R. (2000) Soil health and sustainability: managing the biotic component of soil quality. Applied Soil Ecology 15 (1): 3-11.

Duncan, D.B. (1955) Multiple range and multiple F test. Biometrics 11: 1-112.

Gregorich, E.G., Monreal, C.M., Carter, M.R., Angers, D.A. and Ellert, B.H. (1994) Towards a minimum data set to assess soil organic matter quality in agricultural soils. Canadian Journal of Soil Science 74 (4):367-385.

Kauffmann, S., Sombrooek, W. and Mantel, S. (1998) Soils of rainforests: characterization and major constraints of dominant forest soils in the humid tropics, In: "Soils of Tropical Forest Ecosystems", A. Schulte and D. Ruhiyat (Ed.), pp. 9-20, Characteristics Ecology and Management, Springer-Verlag, Berlin,.

Miller, M.P., Singer, M.J. and Nielson, D.R. (1988) Spatial variability of wheat yield and soil properties on complex hills. Soil Sci. Soc. Am. J. 25, 2167.

Mohanty, M. and Painuli, D.K. (2004) Land preparatory tillage effect on soil physical environment and growth and yield of rice in a Vertisol. Journal of the Indian Society of Soil Science 51(3): 223-228.

Mohanty, M., Pahnuli, D.K. and Mandal, K.G. (2003) Effect of puddling intensity on temporal variation in soil physical conditions and yield of rice (Oryza sativa L.) in a vertisol of central India. Soil Tillage Res. 76: 83-94.

Motschenbacher, J.M., Kristofor, R.B. and Merle, M.A. (2011) Long-term rice-based cropping system effects on near-surface soil compaction. Agric. Sci. 2: 117-124.

MSTAT-C (1983) A software package for the design, management and analysis of agronomic experiments (Version 2.0). Michigan State University, Mississippi, MI, USA .

Mudgal, A., Anderson, S.H., Baffaut, C., Kitchen, N.R. and Sadler, E.J. (2010) Effects of long-term soil and crop management on soil hydraulic properties for claypan soils. J. Soil Water Conservat. 65: 393-403.

Nizami, M.M.I., Zia, M.S. and Saleem, M. (1997) Phosphorus requirements of maize under three tillage practices in different soil series in rainfed conditions. Pak. J. Soil Sci. 18: 66-69.

Nkana, J.C.V. and Tonye, J. (2003) Assessment of certain soil properties related to different land-use systems in the Kaya watershed of the humid forest zone of Cameroon. Land Degrad. Dev. 14: 57-67.

Oguike, P.C. and Mbagwu, J.S.C. (2009) Variations in some physical properties and organic matter content of soils of coastal plain sand under different land use types. World Journal of Agricultural Sciences. 5 (1): 63-69.

Okasha, E.M., El-Ganayni, A.A., Abdou, M.A.A. and EL-Khoby, W.M. (2009) Influence of irrigation intervals, some cultivars and plant spacing on growth, yield and its components in rice part (1) vegetative growth. Agric. Biolog. Sci. 5: 506-514.

Egypt. J. Soil Sci. 53, No. 2 (2013) 
Rane, D.B. and Varade, S.B. (1972) Hydraulic conductivity as an index for evaluating the performance of different puddlers. J. Agric. Eng. 9: 11-16.

Rautaray, S.K., Watts, C.W. and Dexter, A.R. (1997) Puddling effects on soil physical parameters. Agric. Mech. Asia Afr. Lat. Am. 28: 37-40.

Reichert, J.M., Suzuki, L.E.A.S., Reinert, D.J., Horn, H. and Hakansson, I. (2009) Reference bulk density and critical degree of compactness for no-till crop production in subtropical highly weathered soils. Soil Tillage Res. 102: 242-254.

Reynolds, W.D. (2008) Saturated hydraulic properties: laboratory methods. In: "Soil Sampling and Methods of Analysis", Chapter 75, M.R. Carter and E.G. Gregorich (Ed.), CRC Press Taylor \& Francis, Boca Raton, FL, USA.

Sharma, M.L., Bari, M. and Byrne, J. (1991) Dynamics of seasonal recharge beneath a semiarid vegetation on the Gnangara Mound, Western Australia. Hydrol. Proc. 5: 383-398.

Sharma, P.K. and De Datta, S.K. (1985) Effect of puddling on soil physical properties and processes. In: "Soil Physics and Rice", pp: 217-234, Los Banos, Philippines, IRRI.

Singh, K.B., Jalota, S.K. and Sharma, B.D. (2009) Effect of continuous rice-wheat rotation on soil properties from four agro-ecosystems of Indian Punjab. Commun. Soil Sci. Plant Anal. 40: 2945-2958.

Unger, P.W., Fulton, L.J. and Jones, O.R. (1990) Land leveling effects on soil texture, organic matter contents and aggregate stability. J. Soil Water Conservat. 45: 412415.

USDA Natural Resources Conservation Service (2008) Bulk density. In: "Soil Quality Indicators". 


\section{الآثار طويلة الأجل لاستمرار زراعة الأرز علي الكثافة

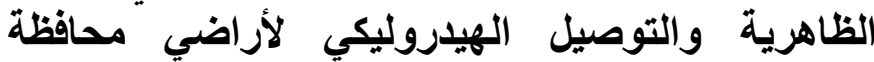

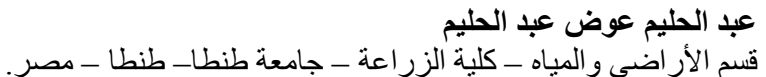

أجريت هذه الدراسة في محافظة الغربية احدي محافظات وسط دلتا النيل لدراسة

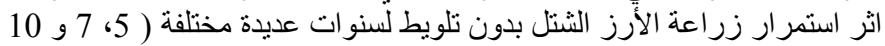

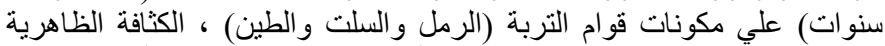

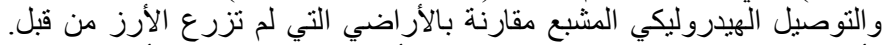

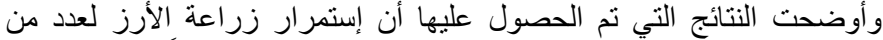

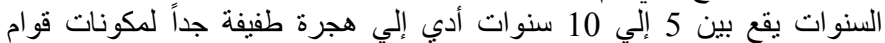

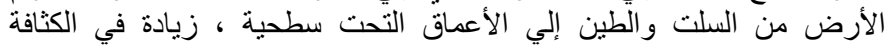

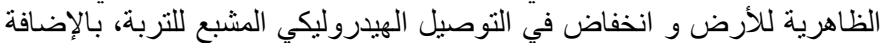

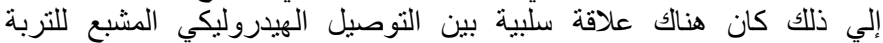
ومحتو اها من السلت والطين بزيادة سنو ات زر اعة الأرز من 5 إلي 10 سنوات التئ. 